University of Montana

ScholarWorks at University of Montana

10-1978

\title{
Attributes of the Deer Hunting Experience: A Cluster-Analytic Study
}

Jacob Hautaluoma

Colorado State University - Pueblo

Perry J. Brown

University of Montana - Missoula, perry.brown@umontana.edu

Follow this and additional works at: https://scholarworks.umt.edu/forest_pubs

Part of the Forest Management Commons

Let us know how access to this document benefits you.

\section{Recommended Citation}

Hautaluoma, Jacob and Brown, Perry J., "Attributes of the Deer Hunting Experience: A Cluster-Analytic Study" (1978). Forest Management Faculty Publications. 40.

https://scholarworks.umt.edu/forest_pubs/40

This Article is brought to you for free and open access by the Forest Management at ScholarWorks at University of Montana. It has been accepted for inclusion in Forest Management Faculty Publications by an authorized administrator of ScholarWorks at University of Montana. For more information, please contact scholarworks@mso.umt.edu. 


\title{
Attributes of the Deer Hunting Experience: $A$ Cluster-Analytic Study
}

\author{
Jacob Hautaluoma and Perry J. Brown
}

\begin{abstract}
Using data from Washington State deer hunters, this paper reports on a cluster analytic study of the attributes of the deer hunting experience. The data were collected by mail questionnaire from 3,924 deer hunters by Potter, Hendee, and Clark (1973). Scaled data were subjected to a variable cluster analysis, and then variable clusters were used in an object cluster analysis of hunters. Several dimensions of the deer hunting experience which add to or detract from satisfaction, and groups of hunters reacting differently to these dimensions, are identified. Nature, harvest, equipment, out-group contact, and skill are identified as important attributes of the hunt, for all deer hunters. Ten groups of Washington State deer hunters, each with a different pattern of response across the dimensions, are identified and discussed. Association of additional hunt and user characteristics with the hunter groups is shown. Uses of these and similar data in game and recreation management are discussed.

KEYWORDS: Recreation behavior, hunting, cluster analysis, hunter satisfaction.

AUTHORS: Perry J. Brown is Associate Professor of Recreation Resources, Colorado State University. Jacob E. Hautaluoma is Associate Professor of Psychology, Colorado State University.
\end{abstract}

Journal of Leisure Research, 1978, Volume 10, Number 4, pp. 271-287. Copyright $\odot 1978$ by the National Recreation and Park Association.

$\mathrm{M}$

any environmental resources are in short supply or in danger from overuse. In order to make well-informed decisions about how to maintain these resources while producing human benefits from them, resource managers need information on the satisfactions which users derive from the resources (Driver and Brown 1975). The rationale behind this suggestion stems from the current interest in consumerism and the long expressed purpose of resource management, "to provide benefits to people."

An aim of this paper is to articulate a procedure for studying the satisfactions people receive from environmental resources. This particular research 
concentrates only on deer with hunters as users, but its method can be generalized to other resources and users as well.

Compared to most consumer goods, environmental resources are often nonconsumable. People enjoy scenery, water sports, and other benefits of the environment without consuming the resource. However, heavy use of environmental resources may deteriorate or destroy them. Deer, and other game animals, are exceptions in that they supply both consumable (meat) and non-consumable benefits to hunters. The general method described here is applicable to resources which are used up as well as to those with non-consumable qualities. Attributes of hunting experiences providing satisfaction are measured in this study.

\section{Game-Related Research}

Writers on game-related experiences have focused on hunting activities, even though hunters are not the only ones who use game. Sight-seers, picnickers, photographers, hikers, and other users also obtain value from animals in the wild. Convenience is one reason for studying hunters and not the other groups. Lists of hunters are available from licensing agencies, making the application of survey research methods possible. Other user populations are much harder to identify. Another reason for studying hunters has been a bias toward looking at the satisfaction from harvesting animals, rather than considering the non-consumptive satisfactions from associating with wildlife.

Several writers have discussed non-harvest attributes of hunting. Kennedy (1970), in a study of the Pocomoke Forest in Maryland, found that hunters valued companionship, camping out, getting out of doors, "getting away from it all," and the suspense and challenge of the hunt. More (1973) studied a sample of hunters from Massachusetts and identified the most positively scored characteristics of hunting as aesthetic benefits, affiliations with people, and the challenge of the hunt. In a study of Arizona hunters, Davis (1967) learned that the benefit to bodily health was mentioned most often, while aesthetios, associations with others, intellectual stimulation, character building, and religious factors were described by a lesser number.

Harvest has been rated a positive attribute by nearly all investigators of the hunting experience, although not as highly as one might expect. Kennedy (1970) found it was rated positively, but ranked fourth in his list of satisfactions. In More's (1973) study, "killing" and "display" of game were both neutrally rated factors, not contributing much to the satisfaction of Massachusetts hunters. In general, it has not been determined how much success or harvest counts in the overall hunting experience. One purpose of the present study is to assess its importance for deer hunters. For the research cited to this point, nature and companionship experiences most strongly add to hunter satisfaction.

Potter, Hendee and Clark (1973) have been working on a "multiplesatisfactions" model of hunting. They have developed a 73 item scale of Likert type items to identify the attributes of the hunting experience providing satisfaction to Washington hunters. The scale has been factor-analyzed into dimensions. The dimensions are attributes of the hunting experience that are rated as either adding to or detracting from the satisfaction derived from 
hunting. Eight dimensions which included more than one item were identified. The dimensions are nature, escapism, shooting, skill, vicariousness, trophy display, harvest, and equipment. Three single-item dimensions reported are in-group companionship, out-group verban contact, and out-group visual contact.

The multiple satisfactions approach to game management (Hendee 1974), for which their data are relevant, suggests that managers should produce opportunities for game-related recreation which recognize the multiple dimensions of the experience. It is suggested that the experience is the important product of recreation and that quality experiences are a function of how well the multiple satisfactions desired by consumers are fulfilled. In recreation much of the impetus for this notion rests on ideas conceptualized by Wagar (1966) while its theoretical base rests in psychology's expectancy-value theory (Lawler 1973). The research reported below adds to the multiple satisfactions approach, though we have chosen some different terminology which we feel makes a clearer distinction among attributes of the physical, social, and managerial environment which facilitate people deriving satisfaction, people's expectations to gain satisfaction and the kinds of satisfaction they expect to gain, and satisfaction itself.

\section{Method}

The research cited above refers to finding dimensions of the hunting experience. Identifying the dimensions of an experience is necessary, but it is only step in understanding a phenomenon. This study takes an additional step and identifies different types of hunters based on their reactions to the different dimensions.

As in other studies, an attempt has been made to identify the dimensions of the deer-hunting experience which produce satisfaction. Utilized for this and the other analyses was a sophisticated cluster analysis system, BC-TRY (Tryon and Bailey 1970). ${ }^{1}$ Scale items were grouped because of their relatedness in mathematical space into clusters or dimensions.

${ }^{1}$ Cluster analysis describes a mathematical procedure which is a special case of the generalized method of grouping variables into independent dimensions (Tryon 1959). All the forms of factor analysis (centroid, principal axis, image, etc.) fall into this category. Cumulative communality key-cluster analysis (the procedure used here) differs from other forms of factor analysis more in its calculations and statistical considerations than in any general conceptual framework.

The major difference between centroid and principal axis factoring and key-cluster factoring lies in the definition of a dimension. It is this difference which makes keycluster factoring more useful in the present context. Centroid and principal axis factoring both define a dimension as the entire set of variables weighted by a specially selected pattern of weights. It is the weights that differ from dimension to dimension, not the variables. Key-cluster factoring, however, defines a dimension as a subset of the variables. The subset is composed of the group of variables most collinear (highly related) to a "pivot" variable. The pivot variable is selected on the basis of its pattern of intercorrelations with the entire variable set. Key-cluster factors (unlike centroid or principal axis factors) are not necessarily orthogonal. These characteristics give keyclustering two important advantages over other factoring procedures. The obliqueness of the factors more closely represents the dimensions in the "real world," and more significantly, by defining a cluster as a subset, much of the unaccounted variance in the system is removed from the defined dimensions. 
After dimensions were identified, the analysis system used the dimensions to type hunters. Typing means scoring each hunter on how much he perceives each dimension contributing to his hunting satisfaction and then considering each hunter's pattern of scores over all the dimensions. To type a person requires that his pattern of scores over the dimensions be similar to that of a group of other hunters (thereafter called his type), and that this group's scores be different from other groups' scores. Hunters within types have patterns of scores over all dimensions similar to those in their type, but different from those of other types.

Typing divides the hunter population into groups who indicate gaining satisfaction from different dimensions of the hunt. Once a type is defined, it is possible to treat it differentially through advertising and the management of environmental resources. Different types of hunters should gain differently from various kinds of environmental resource arrangements, and it should be beneficial for a resource manager to understand the types of users in his clientele, and what they get from the resources he helps to provide for them.

After types of hunters were determined, they were used to forecast other hunter characteristics, such as success in hunting, days hunted, age of hunters, and overall hunting satisfaction. In other words, the hunter types were utilized for purposes other than describing the satisfactions which hunters receive. Types can be the basis for predicting other characteristics that have practical or theoretical values. Tryon and Bailey (1970) argue that types are more effective in making these predictions than is multiple-regression analysis using the aggregate population.

Having other descriptive information about hunter types besides satisfaction data increases the management and theory development potential of typological classification. For example, after knowing the hunter types' satisfaction patterns, it should become possible for managers to make predictions about which types of hunters would be attracted to hunting areas that provide opportunity to gain different kinds of experiences. Hunting areas could be managed to recruit hunters with certain satisfaction patterns. Knowing which types of hunters would be attracted to an area should allow the manager to assess which game policies hunters in that area would favor, the amount of money they would be willing to pay for use of the area, and what satisfactions they expect to receive from the area. Additionally, theoretical principles of hunter behavior can be experimentally examined by predicting hunter characteristics from types and then testing the predictions in on-site situations.

In summary, the method of this study involved determining dimensions of the social and resource situation perceived as providing satisfaction, typing users according to their preferred mix of dimensions, and forecasting other user characteristics from the types identified. It offers possibilities for further research in studying user demands for many kinds of environmental resources.

All the analyses were performed using the BC-TRY multivariable analysis computer system (Tryon and Bailey 1970). It is a cluster analysis system including all the main options of cluster and factor analysis. The system allows both the clustering of variables and persons, comparisons of results on 
different samples, and predictions from typological groupings. This study used many of the kinds of analysis available within the system.

\section{Results}

Reported here is a re-analysis of the Potter et al. (1973) data for 1970 Washington State hunters. This analysis utilized the cluster analysis methodology described above and is different from that originally reported by Potter et al. They had dimensionalized their 73 Likert type scale items utilizing a factor analysis routine, but did not do typological analysis and subsequent forecasting of type characteristics.

\section{Data}

The Potter et al. data were based on a 2 percent sample of all Washington hunters for 1970 . Approximately 85 percent of the sample returned a usable questionnaire. Since only deer hunters were of interest in this study, all other hunters were excluded. The total number of deer hunters from which data were obtained was 3,924 .

\section{Dimensions of Satisfaction in Four Groups of Deer Hunters}

Before the analysis, four groups of deer hunters were identifiable from the Potter et al. sample based upon the variety of game that they hunted. These were: (1) persons who only hunted deer (N 827); (2) persons who hunted deer and other big game ( $N$ 769); (3) persons who hunted deer and small game such as ducks and rabbits (N 1206); (4) persons who hunted deer plus both small and big game ( $\mathrm{N}$ 1113). A cluster analysis was performed on the item responses for each of these subsamples. The clusters which resulted are displayed in Table 1. Dimensions containing only one item identified by Potter et al. are excluded. Each dimension in the right four columns has at least three items in it. The names were assigned to represent the meaning of the dimension as closely as possible, but it should be realized that dimensions having the same names do not necessarily contain identical items, although there is much overlap.

The Nature dimension was important for all kinds of hunters. The Escapism dimension of Potter et al. was not reliably found among the deer hunter groups. Frustration Release, found among the deer hunter groups, is close to Escapism in meaning, but there is only a slight overlap between items in these two dimensions. The Shooting dimension of Potter et al. did not appear for deer hunters, except for the deer-and-small-game group. However, Killing was found for the deer-hunters-only group and the deer-plus-small-andbig-game group. Perhaps, Shooting is a relatively important satisfaction dimension for hunters of small game. Deer and other big game hunters do not get many shots, and hence do not seem to value shooting as a prime source of satisfaction. The Skill dimension was found uniformly across all hunter groups, although among deer hunter groups it was always a late-appearing cluster. The dimension of Easy Hunting, found in all the deer hunter groups except the deer-plus-big-game group, suggests that many deer hunters derive satisfaction from a fast, easy kill, which is not demanding of skill. The vicariousness dimension did not appear for any of the four deer hunter 
groups. The same is true for Trophy Display, except for a weak cluster among those who hunt deer-plus-both-small-and-big-game.

Harvest was found as a relatively unimportant dimension in the Potter et al. results, whereas it was consistently important for the groups of deer hunters. Among the deer hunters the dimension separated into several aspects, including Harvest, Giving Game Away, and Competitive Harvest. Killing was mentioned only for the persons who hunted both big and small game, and Meat Hunting for the group who only hunted deer. The equipment dimension was found for all the deer hunter groups, and the group who hunted all kinds of animals had an additional weak cluster on Working With Weapons.

A suspect dimension in the Potter et al. analysis that appeared for all the deer hunter groups was Out-Group Contact. They found two weak one-item factors on the topic which cannot legitimately be called dimensions. But, the deer hunter groups obtain some satisfaction from contacting or knowing that members of other parties are present in a hunting area.

In summary, the dimensions found for the deer hunter groups were somewhat different from the dimensions of the Potter et al. all-inclusive sample. The deer hunter groups had relatively consistent dimensions as measured by the COMP (comparison) programs of BC-TRY, especially among the strongest clusters. Because of this consistency, it was decided to treat the total sample of Washington deer hunters as homogenous, and not as four separate groups in subsequent analyses. However, to thoroughly investigate the detailed differences among deer hunters would require analysis of each individual group.

\section{Typing}

After identifying some of the dimensions of satisfaction that hunters receive from deer hunting, the typing programs of BC-TRY were used to classify the types of deer hunters in the sample according to their patterns of satisfaction over the dimensions. Four criteria were used to select the dimensions to be used in the typological analysis. The dimension had to be common to all four groups of deer hunters. It had to be relatively independent of the other dimensions. The strength of the dimension, or order of appearance in the list, was considered. And, the consistency of items appearing in the dimension over the four hunter groups was important for retaining the dimension. Five dimensions were retained for the typological analysis based on these criteria. Table 2 contains the dimensions and items selected for use in the typological analysis. The names of the dimensions are Nature, Harvest, Equipment, Out-Group Contact, and Skill.

In doing the typological analysis, each hunter was scored on each dimension. A pattern or signature across all five scores was established for each hunter. Then, the hunters' score patterns were compared and groups of hunters with similar patterns were formed. Several typing iterations were performed on the computer (an average of 20 times each on the data used here) until a stable set of patterns was found. Nearly all of the hunters were assigned to one of the groups.

Results of the typological analysis are shown in Table 3. Across the top of the table are the five dimensions selected for typological analysis and down 
TABLE 1

Dimensions of Hunting Satisfaction for Different Kinds of Hunters ${ }^{a}$

\begin{tabular}{|c|c|c|c|c|}
\hline $\begin{array}{l}\text { All Hunters } \\
\text { (N 5540) }\end{array}$ & $\begin{array}{l}\text { Only Hunt Deer } \\
\text { (N 827) }\end{array}$ & $\begin{array}{l}\text { Ondy Hunt Deer } \\
\text { and Big Game } \\
\text { (N 769) }\end{array}$ & $\begin{array}{l}\text { Only Hunt Deer } \\
\text { and Small Game } \\
\text { (N 1206) }\end{array}$ & $\begin{array}{l}\text { Hunt Deer and } \\
\text { Big and Small Game } \\
\text { (N 1113) }\end{array}$ \\
\hline Nature & Nature & Giving game away & Harvest & Harvest \\
\hline Escapism & Giving game away & Harvest & Nature & Giving game away \\
\hline Shooting & Harvest & Nature & Giving game away & Nature \\
\hline Skill & Equipment & Out-group contact & Out-group contact & Out-group contact \\
\hline Vicariousness & Frustration release & Frustration release & Frustration release & Frustration release \\
\hline Trophy display & Out-group contact & Equipment & Equipment & Equipment \\
\hline Harvest & Competitive harvest & Competitive harvest & Enjoyment of hunting & Killing \\
\hline \multirow[t]{5}{*}{ Equipment } & Killing & Enjoyment of hunting & Easy hunting & Skill \\
\hline & Easy hunting & Skill & Shooting & Easy hunting \\
\hline & Meat hunting & & Skill & Display of game \\
\hline & Skill & & & Working with weapons \\
\hline & Enjoyment of hunting & & & \\
\hline
\end{tabular}

a The Potter et al. (left column) results were found with an unspecified type of factor analysis, while the results for the four different kinds of deer hunters are from a 
Selected Dimensions and Items Representing Attributes of the Deer Hunting Experiences in Washington 1970. ${ }^{a}$ (Reliabilities in parentheses).

\author{
Nature (.86) ${ }^{b}$ \\ Being close to Nature \\ Getting away from civilization \\ Just being outdoors \\ The smell and sounds of the woods and field \\ Physical exercise \\ Camping out while hunting \\ Getting away from everyday problems \\ At least seeing some wildlife \\ Harvest (.88) $b$

\section{Getting my bag limit} \\ The amount of game bagged \\ Showing game I have bagged to family and \\ friends \\ Bringing game home \\ Bagging as much game as my hunting \\ companions \\ Bagging a very large animal or bird \\ Killing game \\ Bagging more game than hunters in other \\ parties
}

\section{Seeing game fall as I shoot}

Equipment (.78) b

Having the best of hunting equipment

Being a well-equipped hunter

Comparing my equipment with other hunters'

Cleaning and maintaining my hunting equipment

\section{Out-Group Contact (.73) ${ }^{\text {b }}$}

Seeing hunters from other parties

Talking with hunters in other parties

Seeing hunters in other parties having success

Seeing very few other hunters while hunting

Skill (.76) ${ }^{\text {b }}$

Outsmarting game

Stalking game

Making a difficult shot

Teaching someone else the skills of hunting

a Responses to the items were recorded on a nine-point scale ranging from "Extremely Detracts from Your Hunting Satisfaction" to "Extremely Adds to ..."

b The rehabilities are parallel-forms coefficients (Tryon and Bailey 1970: 58-59), a kind of internal consistency measure.

the left side are the ten hunter types that were found and the number of persons in each type. Most hunters were assigned to one of the types, but 342 (8.7 $\%$ ) were not placed because they had unique patterns. Finding this proportion of non-classifiable subjects is not unusual in typing. The cells in the table describe the importance of the dimension to hunter satisfaction. Cells with the word "neutral" indicate that the dimension neither adds to nor detracts from the hunting experience. The numbers in the cell represent the mean degree of contribution to satisfaction that the hunters scaled on their questionnaires. The scale ranged from plus four (extremely adds) to minus four (extremely detracts).

Type 1 might be called the "minimum gratification" type. Most of the dimensions did not contribute to either the satisfaction or dissatisfaction of these hunters. Out-group contact is slightly negative in their experience. As a group they look like potential dropouts from deer hunting. Type 2 hunters 


\section{TABLE 3}

\begin{tabular}{|c|c|c|c|c|c|c|}
\hline \multicolumn{7}{|c|}{$\begin{array}{c}\text { Washington State Deer Hunter Types Based on Empirically } \\
\text { Derived Scores On Satisfaction Dimensions }\end{array}$} \\
\hline Type b & $\mathbf{N}$ & Nature & Harvest & Equipment & $\begin{array}{l}\text { Out-group } \\
\text { Contact }\end{array}$ & Skill \\
\hline 1 & 299 & Neutral (0) & Neutral (0) & Neutral (0) & $\begin{array}{l}\text { Somewhat } \\
\text { Detracts }(-1)\end{array}$ & Neutral (0) \\
\hline 2 & 316 & $\begin{array}{l}\text { Extremely } \\
\text { Adds (4) }\end{array}$ & Neutral (0) & Neutral (0) & $\begin{array}{l}\text { Somewhat } \\
\text { Detracts }(-1)\end{array}$ & $\begin{array}{l}\text { Highly } \\
\text { Adds (3) }\end{array}$ \\
\hline 3 & 415 & $\begin{array}{l}\text { Moderately } \\
\text { Adds (2) }\end{array}$ & $\begin{array}{l}\text { Moderately } \\
\text { Adds (2) }\end{array}$ & Neutral (0) & $\begin{array}{l}\text { Somewhat } \\
\text { Adds (1) }\end{array}$ & $\begin{array}{l}\text { Highly } \\
\text { Adds (3) }\end{array}$ \\
\hline 4 & 332 & $\begin{array}{l}\text { Extremely } \\
\text { Adds (4) }\end{array}$ & $\begin{array}{l}\text { Moderately } \\
\text { Adds (2) }\end{array}$ & $\begin{array}{l}\text { Somewhat } \\
\text { Adds (2) }\end{array}$ & $\begin{array}{l}\text { Moderately } \\
\text { Detracts }(-2)\end{array}$ & $\begin{array}{l}\text { Highly } \\
\text { Adds (3) }\end{array}$ \\
\hline 5 & 362 & $\begin{array}{l}\text { Extremely } \\
\text { Adds (4) }\end{array}$ & Neutral (0) & Neutral (0) & $\begin{array}{l}\text { Somewhat } \\
\text { Detracts }(-1)\end{array}$ & Neutral (0) \\
\hline 6 & 371 & $\begin{array}{l}\text { Moderately } \\
\text { Adds (2) }\end{array}$ & $\begin{array}{l}\text { Highly } \\
\text { Adds (3) }\end{array}$ & $\begin{array}{l}\text { Highly } \\
\text { Adds (3) }\end{array}$ & $\begin{array}{l}\text { Somewhat } \\
\text { Adds (1) }\end{array}$ & $\begin{array}{l}\text { Somewhat } \\
\text { Adds (1) }\end{array}$ \\
\hline 7 & 304 & $\begin{array}{l}\text { Extremely } \\
\text { Adds (4) }\end{array}$ & $\begin{array}{l}\text { Somewhat } \\
\text { Adds (2) }\end{array}$ & $\begin{array}{l}\text { Highly } \\
\text { Adds (3) }\end{array}$ & $\begin{array}{l}\text { Somewhat } \\
\text { Detracts }(-1)\end{array}$ & $\begin{array}{l}\text { Extremely } \\
\text { Adds (+4) }\end{array}$ \\
\hline & & Extremely & Somewhat & Moderately & Moderatelv & Highly \\
\hline 8 & 417 & Adds (4) & Adds (1) & Adds (2) & Adds (2) & Adds (3) \\
\hline 9 & 359 & $\begin{array}{l}\text { Extremely } \\
\text { Adds (4) }\end{array}$ & $\begin{array}{l}\text { Extremely } \\
\text { Adds (4) }\end{array}$ & $\begin{array}{l}\text { Extremely } \\
\text { Adds (4) }\end{array}$ & $\begin{array}{l}\text { Moderatel: } \\
\text { Adds (2) }\end{array}$ & $\begin{array}{l}\text { Extremely } \\
\text { Adds (4) }\end{array}$ \\
\hline 10 & 407 & $\begin{array}{l}\text { Extremely } \\
\text { Adds (4) }\end{array}$ & $\begin{array}{l}\text { Extremely } \\
\text { Adds (4) }\end{array}$ & $\begin{array}{l}\text { Moderately } \\
\text { Adds (2) }\end{array}$ & $\begin{array}{l}\text { Sorrewhat } \\
\text { Detracts }(-1)\end{array}$ & $\begin{array}{l}\text { Extremely } \\
\text { Adds (4) }\end{array}$ \\
\hline & & Avg. Mean (3.2) & Avg. Mean (1.7) & Avg. Mean (1.6) & Avg. Mean (- .1) & Avg. Mean (2.5) \\
\hline
\end{tabular}

a The numbers in parentheses indicate the approximate mean satisfaction level for the type on the dimension. The over all mean for the dimension is in the bottom row. These means were calculated after the typing which simply determines the position of the types relative to each other on standardized scores

without regard to absolute level of satisfaction.

b There were 342 hunters unassigned to type because of the uniqueness of their patterns across the dimensions. 
appreciate the benefits of nature and having a chance to demonstrate their skill, but they are somewhat bothered by out-group contact. Type 3 gets the most benefit from demonstrating skill, but also gets some from the other dimensions, except using hunting equipment. Type 4 hunters are most gratified by nature and skill satisfactions and a little less so by harvest and equipment. They are the type most strongly offended by out-group contact. Type 5 wants nature benefits from hunting and not much else. They do not particularly appreciate contacting others in the wild. Type 6 hunters get most satisfaction from the harvest and equipment dimensions, but some pleasure from all of them. Type 7 hunters value the nature, skill, and equipment dimensions a great deal, care somewhat about harvesting an animal, and would rather not contact other persons while hunting. Type 8 hunters are generally positive about all the dimensions. They are highest on nature and skill benefits and least positive on harvest. Along with Type 9, they were the ones who value out-group contact the most. Type 9 hunters are extremely positive about all the dimensions. They get only moderate satisfaction from out-group contact, but no other type scored higher than them on this dimension. Type 10 hunters gain a great deal of satisfaction from the nature, harvest, and skill dimensions. They get some satisfaction from equipment, but they are slightly negative about encountering hunters from other groups.

Among all dimensions, nature contributes most to hunter satisfaction. Only Type 1 has as low as a neutral rating on nature. The skill dimension contributed a little less than nature to the satisfaction of all hunter types. Harvest did not detract from the experience of hunting for any type, but Types 1, 2, and 5 are neutral toward it. Types 6, 9, and 10 see it as an important basis of satisfaction. For the Washington hunter, harvest satisfaction was less important than that from both nature and skill. The equipment dimension obtained the most neutral ratings. For only Types 6,7 , and 9 does it add a great deal to their experience. As might be expected, out-group contact produced the most unfavorable reaction from hunters, but the responses were marked by a lack of extreme scores in either direction. No type was exactly neutral toward it and for six of the ten types it was a mildly negative dimension. A surprising result is that for at least four types, Types $3,6,8$, and 9, out-group contact added to their experience.

\section{Forecasting from Types}

It was mentioned previously that a feature of the BC-TRY system is its capability to identify associations between types and other variables. The Potter et al. questionnaire contained a number of items on demographic characteristics, hunting days, hunting success, preferences for kinds of hunting, and other factors, designed to enable description of the hunter population.

The BC-TRY program uses a technique to determine the relationships of variables to types which relies on Monte Carlo sampling. (In the computer, several hundred samples of the type's size are drawn from the total sample, providing a distribution of sample means against which the type's actual mean is compared). The end product of the routine is a probability statement for the likelihood of finding a particular type's mean on a variable based on samples of the type's size drawn from the total sample.

Results of the prediction analysis are summarized in Table 4. For Type 1 
TABLE 4

\begin{tabular}{|c|c|c|c|c|c|c|c|c|}
\hline \multirow[b]{3}{*}{ Type } & \multicolumn{8}{|c|}{ Characteristics of Hunters That Have Been Significantly Predicted By Types } \\
\hline & \multicolumn{2}{|c|}{$\begin{array}{l}\text { Degree of Satisfaction } \\
\text { Received from hunting } b\end{array}$} & \multicolumn{2}{|c|}{$\begin{array}{l}\text { Importance of Hunting } \\
\text { Compared to Other Forms } \\
\text { of Outdoor Recreation c }\end{array}$} & \multicolumn{2}{|c|}{$\begin{array}{l}\text { Preference Rank of Deer } \\
\text { Hunting Compared to Other } \\
\text { Kinds of Hunting } d\end{array}$} & \multicolumn{2}{|c|}{$\begin{array}{l}\text { Days Spent Hunting } \\
\text { Deer During } 1970\end{array}$} \\
\hline & Mean & Direction & Mean & Direction & Mean & Direction & Mean & Direction \\
\hline 1 & 2.92 & Low & 2.99 & Low* & 1.47 & & 6.88 & Low ${ }^{* *}$ \\
\hline 2 & 3.52 & High* & 3.41 & & 1.54 & & 7.15 & \\
\hline 3 & 3.29 & & 3.33 & & 1.53 & & 6.80 & Low $^{* *}$ \\
\hline 4 & 3.37 & $\mathrm{High}^{* *}$ & 3.38 & & 1.65 & Low* & 7.31 & \\
\hline 5 & 3.07 & Low* & 2.94 & Low* & 1.47 & & 6.61 & Low* \\
\hline 6 & 3.14 & Low & 3.34 & & 1.45 & $\mathrm{High}^{* *}$ & 7.76 & \\
\hline 7 & 3.50 & $\mathrm{High}^{* *}$ & 3.58 & High* & 1.60 & Low ${ }^{*}$ & 7.79 & \\
\hline 8 & 3.43 & High* & 3.43 & $\mathrm{High}^{* *}$ & 1.48 & & 7.90 & \\
\hline 9 & 3.39 & $\mathrm{High}^{* *}$ & 3.66 & High $^{*}$ & 1.57 & & 8.92 & High $^{*}$ \\
\hline 10 & 3.39 & $\mathrm{High}^{*}$ & 3.59 & High $^{*}$ & 1.60 & Low** & 7.47 & \\
\hline \multirow[t]{2}{*}{$\begin{array}{l}\text { Range } \\
\text { of } \\
\text { Type } \\
\text { Means }\end{array}$} & $\begin{array}{l}3.27- \\
3.28\end{array}$ & & $\begin{array}{l}3.35- \\
3.36\end{array}$ & & $\begin{array}{l}1.51- \\
1.52\end{array}$ & & $\begin{array}{l}7.45- \\
7.49\end{array}$ & \\
\hline & $\begin{array}{r}\mathrm{b}_{2} \\
3 \\
4\end{array}$ & $\begin{array}{l}\text { Somewhat Satisfying } \\
\text { Moderately Satisfying } \\
\text { Extremely Satisfying }\end{array}$ & $\begin{array}{rr}c^{2} & \mathrm{~S} \\
3 & \mathrm{~N} \\
4 & \mathrm{E}\end{array}$ & $\begin{array}{l}\text { Somewhat Significant } \\
\text { Moderately Significant } \\
\text { Extremely Significant }\end{array}$ & ${ }^{d}$ Low & e equal to & & \\
\hline
\end{tabular}

a The significance levels are determined by a Monte Carlo method. For each method in the table the computer draws a large number of samples of the type's size from the $\infty$ whole set of deer hunters. It calculates an empirical sampling distribution of means. The probability value is the likelihood of finding a mean as extreme as the type's distribution. The range of item means found for the ten types is in the bottom row. 


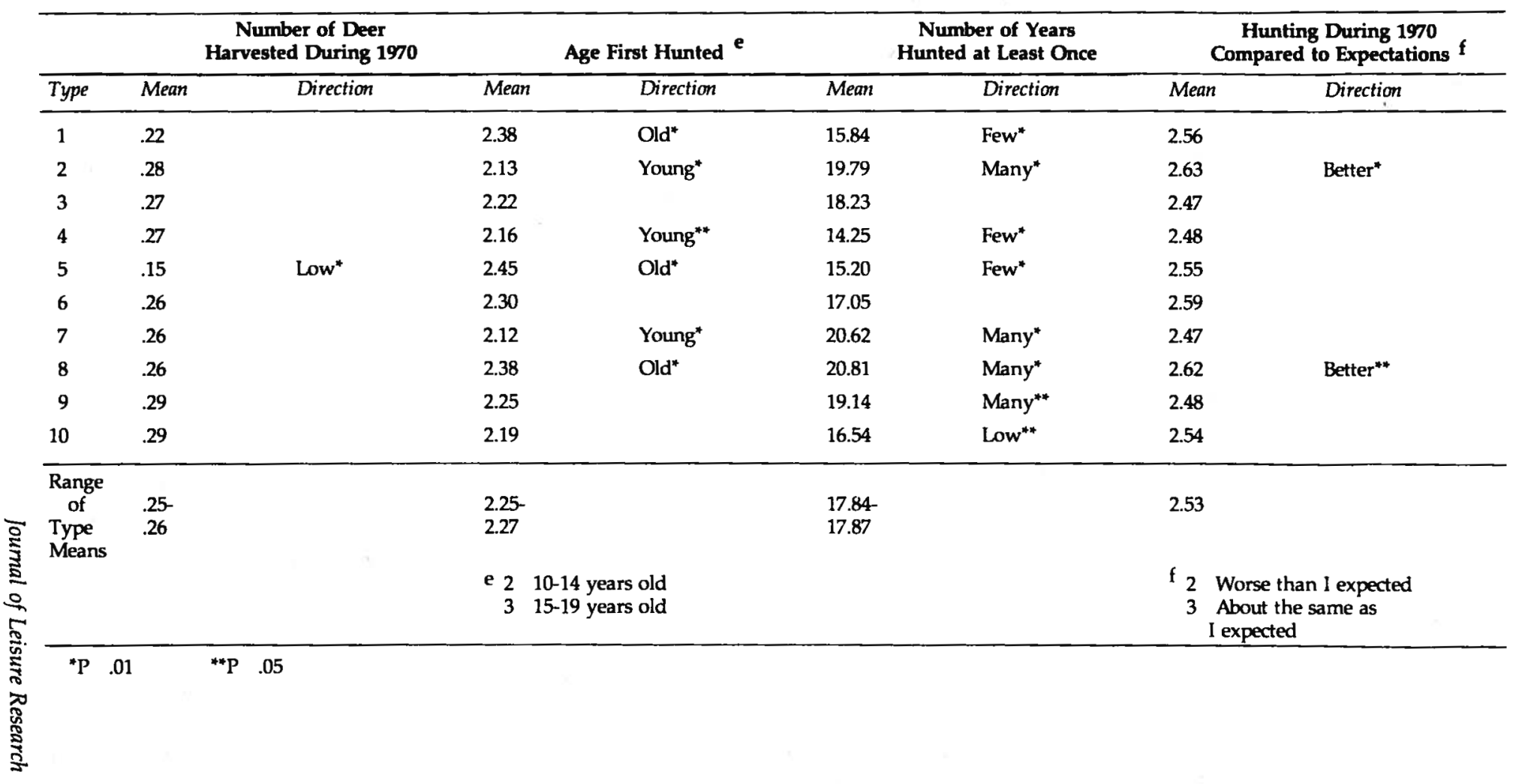




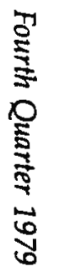

TABLE 4 CONTINUED

\begin{tabular}{|c|c|c|c|c|c|c|c|c|}
\hline & & $\begin{array}{c}\text { Change in Interest } \\
\text { in Hunting During } \\
\text { Past Few Years } \mathbf{g}\end{array}$ & & Where Do You Live Now $h$ & & $\begin{array}{l}\text { Where Did You Spend } \\
\text { Most of Your Youth i }\end{array}$ & & $\begin{array}{l}\text { Where Did Your } \\
\text { Father Spend Most } \\
\text { of His Youth j }\end{array}$ \\
\hline Type & Mean & Direction & Mean & Direction & Mean & Direction & Mean & Direction \\
\hline 1 & 2.01 & Decrease $^{*}$ & 2.34 & More rural* & 2.61 & & 2.88 & \\
\hline 2 & 1.94 & Decrease $^{* *}$ & 2.02 & More urban ${ }^{* *}$ & 2.58 & & 2.95 & \\
\hline 3 & 1.94 & Decrease $^{* *}$ & 2.20 & & 2.71 & More rural ${ }^{*}$ & 3.00 & \\
\hline 4 & 1.84 & & 2.11 & & 2.42 & More urban** & 2.80 & More urban** \\
\hline 5 & 2.00 & Decrease $^{*}$ & 2.11 & & 2.43 & More urban** & 2.92 & \\
\hline 6 & 1.84 & & 2.20 & & 2.62 & & 2.88 & \\
\hline 7 & 1.80 & & 2.04 & & 2.57 & & 2.88 & \\
\hline 8 & 1.79 & Increase $^{* *}$ & 2.06 & & 2.57 & & 2.97 & \\
\hline 9 & 1.70 & Increase* & 2.11 & & 2.46 & & 2.95 & \\
\hline 10 & 1.82 & & 2.05 & More urban* & 2.38 & More urban & 2.94 & \\
\hline \multirow[t]{2}{*}{$\begin{array}{l}\text { Range } \\
\text { of } \\
\text { Type } \\
\text { Means }\end{array}$} & $\begin{array}{l}1.86- \\
1.87\end{array}$ & & $\begin{array}{l}2.54- \\
2.13\end{array}$ & & $\begin{array}{l}2.54 \\
2.55\end{array}$ & & 2.91 & \\
\hline & \multicolumn{2}{|c|}{$\begin{aligned} & g_{1} \text { Increased } \\
& 2 \text { Remained about } \\
& \text { the same } \\
& 3 \text { Decreased }\end{aligned}$} & $h_{2}$ & $\begin{array}{l}\text { Small Town } \\
\text { Rural Area }\end{array}$ & ${ }^{\mathrm{i}} 2 \mathrm{~s}$ & $\begin{array}{l}\text { Small Town } \\
\text { Rural Area }\end{array}$ & $\mathrm{j}_{2}$ & $\begin{array}{l}\text { Small Town } \\
\text { Rural Area }\end{array}$ \\
\hline
\end{tabular}

${ }^{*} \mathrm{P} \quad .01$

${ }^{* *} \mathrm{P}<.05$ 
TABLE 4 CONTINUED

\begin{tabular}{|c|c|c|c|c|c|c|c|c|}
\hline & & Age $k$ & & $\operatorname{Sex} 1$ & & Education Level $\mathbf{m}$ & & Yearly Income (1970) ${ }^{n}$ \\
\hline Type & Mean & Direction & Mean & Direction & Mean & Direction & Mean & Direction \\
\hline 1 & 3.24 & & 1.05 & & 3.65 & Low $^{* *}$ & 3.43 & Low \\
\hline 2 & 3.46 & Older** & 1.04 & & 4.11 & High* & 4.14 & High" \\
\hline 3 & 3.36 & & 1.05 & & 4.14 & High $^{*}$ & 3.91 & High" \\
\hline 4 & 2.85 & Younger* & 1.02 & More Males* & 4.19 & $\mathrm{High}^{*}$ & 3.99 & High" \\
\hline 5 & 3.26 & & 1.11 & More Females" & 4.16 & High* & 3.74 & \\
\hline 6 & 3.14 & Younger" & 1.04 & & 3.45 & Low & 3.42 & Low* \\
\hline 7 & 3.38 & & 1.02 & More Males* & 3.88 & & 3.99 & High" \\
\hline 8 & 3.65 & Older* & 1.08 & More Females & 3.67 & Low* & 3.70 & \\
\hline 9 & 3.22 & & 1.04 & & 3.28 & Low & 3.42 & Low ${ }^{*}$ \\
\hline 10 & 3.04 & Younger" & 1.04 & & 3.84 & & 3.83 & \\
\hline \multirow{2}{*}{$\begin{array}{l}\text { Range } \\
\text { of } \\
\text { Type } \\
\text { Means }\end{array}$} & $\begin{array}{l}3.27- \\
3.29\end{array}$ & & 1.05 & & $\begin{array}{l}3.78- \\
3.80\end{array}$ & & $\begin{array}{l}3.69- \\
3.70\end{array}$ & \\
\hline & $\begin{array}{r}\mathbf{k}_{2} \\
3 \\
4\end{array}$ & $\begin{array}{l}21-30 \text { years old } \\
31-40 \text { years old } \\
41-50 \text { years old }\end{array}$ & $\begin{aligned} 1_{1} & \text { Male } \\
2 & \text { Female }\end{aligned}$ & & $\begin{array}{r}m_{3} \\
4 \\
5\end{array}$ & $\begin{array}{l}\text { Some high school } \\
\text { Completed high school } \\
\text { Some college }\end{array}$ & $\begin{array}{r}n_{3} \\
4 \\
5\end{array}$ & $\begin{array}{l}\$ 6,000-8,999 \\
\$ 9,000-11,000 \\
\$ 12,000-14,999\end{array}$ \\
\hline${ }^{*} \mathrm{P}<.01$ & & ${ }^{*} \mathrm{P}<.05$ & & & & & & \\
\hline
\end{tabular}


hunters, the following results are shown. They ranked the lowest of the types on satisfaction received from hunting, although they rated it "moderately satisfying." They were second lowest in ranking hunting as important compared to other forms of outdoor recreation. They ranked third lowest on number of days spent hunting deer during 1970; they hunted almost a week. They were relatively old when they started to hunt and have hunted a few less years than the other types. They were the most likely to say their interest in hunting had decreased during the last several years, although their average response was that it had "remained about the same." Type 1 hunters tended to be from more rural areas than the other types. Their education and income level was relatively low. Results are shown for the other types as well.

Of the items used to separate types, some produced greater discrimination than others. The item about satisfaction gained from hunting produced significant discriminations among all types, except Type 3 . In reality, this item is simply a summary statement of the satisfaction obtained from hunting. The number of discriminations produced by the other variables is shown in the table, with the item asking about the number of deer harvested during the 1970 season producing the least discrimination.

\section{Conclusions}

The method of this research can be used to study the demand for many kinds of environmental experiences. Users' expressions of satisfaction or dissatisfaction toward elements of the experience can be dimensionalized with cluster analysis. Then the dimensions can be utilized to define types of users. These user types are segments of the user population receiving differential gratification from an experience. Knowledge of different types enables the making of management decisions for environmental resources based upon the resource and social elements which provide user satisfaction. An understanding of users can also be enhanced by examining items that might be expected to differentiate user types. In this study, the types were analyzed over demographic, satisfaction, hunting success, hunting effort, importance of hunting and experience variables. With more refined hypotheses, the understanding of the types could be increasingly improved, and sharp descriptions of them obtained.

There are several conclusions which can be derived from our re-analysis of the Potter et al. (1973) data. The results suggest that more attention might be directed toward producing hunting opportunities that can provide nature and skill related satisfaction. For all the deer hunters studied, nature and skill were the most positively rated attributes of the experience in terms of providing satisfaction. In general, independent of how other attributes were rated, these two were rated quite positively. The contrast between nature and harvest appears particularly striking, and three hunter types (1,2, and 5) were identified for whom hunting in low harvest areas would not detract from the experience. Two of these groups would be gratified by nature oriented experiences which include seeing game but not necessarily bagging it, while the other, Type 1, is likely to be a hunting drop-out because hunting provides them little gratification.

Another conclusion is that out-group contact, commonly called crowding 
when at unacceptable levels, is quite tolerable witin acceptable limits for four of the hunter types $(2,3,8$, and 9). Having other hunters around is not uniformly bad to all the types, and some types say they would appreciate having other hunters around. Future research might focus on the point at which different hunter experience types say there are too many other hunters present.

The data clearly show that some deer hunters gain more satisfaction from the hunting dimensions studied than do other hunters. If these dimensions represent a valid set to describe deer hunting, then one might ase these satisfaction indications in allocating and managing game resources. For instance, Hendee (1972 and 1974) has argued that the hunters who are most dependent on hunting for their satisfactions in life should be catered to more than those who describe themselves as having alternative means of gaining satisfaction. Utilizing this rationale, one might argue that those hunting groups who highly value the harvest and skill components of deer hunting should be given special consideration when allocating scarce game related resources. Implicit in this conclusion is the notion that hunters emphasizing other hunt attributes have many substitute activities which provide the same kinds of satisfaction.

Finally, our re-analysis of the Potter et al. data can be utilized to help answer questions about the equity inherent in game resource allocation. The kinds of hunter groups described (and thus hunt experiences desired) can be related to age, income, sex, and other population descriptors. While the types of hunters can be used to describe experiences desired, the population descriptors can be used to socially describe groups of hunters desiring specific experiences. When these data are compared with local or state population data and with the actual distribution of deer hunting opportunities, the equity implications of present Washington State deer hunting policy can be determined.

In addition to these empirically based conclusions, we can also suggest some general applications of the methods used in our re-analysis of the Potter et al. data. Valuing specific hunting sites, estimating demand for hunting experiences, and allocating game related resources are activities for which our methodology can provide information.

Wennegren and Fullerton (1975) have identified that there are large differences between the location and amenity value of hunting sites, and that the total site value is composed of these two components. The methods which we utilized fit well within these concepts and enable the identification, from the hunters' perspective, of the site attributes which have value. In order to supply highly valued resources, the manager can manipulate key resource elements to produce a desired mix of site attributes.

In estimating demand, the method is used to delineate specific hunting experiences for which management might provide opportunity. Rather than treating all deer hunting as one experience, the method enables the identification of more discrete experience packages and the size of the hunter groups relating favorably to the different experiences. In the sense that Wagar (1966) discussed a need to provide a spectrum of recreation facility types within an activity category (e.g., camping), this method enables identifying the experience spectrum demanded. Such information enables deriv- 
ing economic estimates of willingness-to-pay for specific hunting or other recreational experiences. This would produce demand estimates for specific products rather than for classes of products as have been generated many times.

The output of the method is also relevant to resource allocation decisions (apart from economic demand estimation and site valuation). Presently, various mathematical models are used as resource allocation aids. Very popular are linear programming models, among which is goal programming. The information obtained, utilizing the method described here, about groups and the kinds of experiences which provide them satisfaction, can be utilized as the goal sets in these models. Also, information about experience attributes can be used to specify the dimensions of other parts of a goal programming model. For instance, land unit descriptions (e.g., response unit classifications) and the identification of management alternatives might be aided by the kinds of information produced by utilizing the method we described.

Finally, the method used has applicability beyond analysis of deer hunting. Berry and Brown (1976) have used it in an analysis of quality of life values in a regional planning exercise (Brown et al. 1976), and it is being tested for applicability to wilderness and natural history interpretation management situations as well as being used in additional game management studies. It appears to have potential for use in many resource planning and management situations.

\section{References}

Berry, J. K. and Brown, P. J. 1976. Environmental values and regional planning. Regional Resource Planning Program, Colorado State University, $73 \mathrm{pp}$.

Brown, P. J., Driver, B. L., and Stankey, G. H. 1976. Human behavioral science and recreation management. Proceedings of the 16th World Congress of the International Union of Forestry Research Organizations. Volume VI.

Brown, P. J. et al. 1976. Environmental carrying capacity: case study of Grand County Area, Colorado. Report to the Environmental Protection Agency, Regional Resource Planning Program, Colorado State University, 186 pp.

Davis, W. C. 1967. Values of hunting and fishing in Arizona in 1965. College of Business and Public Administration, University of Arizona.

Driver, B. L. and Brown, P. J. 1975. A social-psychological definition of recreation demand, with implications for recreation resource planning. In Assessing Demand for Outdoor Recreation. National Academy of Sciences, pp. 65-88. (Reprinted by the Bureau of Outdoor Recreation).

Hendee, J. C. 1972. Managernent of wildlife for human benefits. Paper presented to the Western Association of State Game and Fish Commissioners. Xerox.

1974. A multiple-satisfaction approach to game management. Wildlife Society Bulletin 2(3):104-113.

Kennedy, J. J. 1970. A consumer analysis approach to recreational decisions: deer hunters as a case study. Unpublished Ph.D. dissertation, Virginia Polytechnic Institute and State University, Blacksburg, Va.

Lawler, E. E., III. 1973. Motivation in work organizations. Monterey, California: Brooks/Cole. 224 pp.

More, T. A. 1973. Attitudes of Massachusetts hunters. In Human dimensions in wildlife programs (edited by J. C. Hendee and C. Schoenfeld). The Wildlife Management Institute. pp. 72-76.

Potter, D. C., Hendee, J. C., and Clark, R. N. 1973. Hunting satisfactions: game, guns, or nature. In Human dimensions in wildlife programs (edited by J. C. Hendee and C. Schoenfeld). The Wildlife Management Institute. pp. 62-71.

Tryon, R. C. 1959. Domain sampling formulation of cluster and factor analysis. Psychometrika, 24:113-135.

Tryon, R. C. and Bailey, D. E. 1970. Cluster analysis. Mc-Graw-Hill, New York City: 341 pp.

Wagar, J. A. 1966. Quality in outdoor recreation. Trends 3(3):9-12.

Wennergren, E. B. and Fullerton, H. H. 1975. Estimating quality and location values of recreation resources. Journal of Leisure Research 4(3): 170-183.

Fourth Quarter 1979 